\title{
PENERAPAN MODEL PEMBELAJARAN KOOPERATIF TIPE TEAM GAMESTOURNAMENT (TGT) UNTUK MENINGKATKAN HASIL BELAJARMATEMATIKA SISWA KELAS V SEKOLAH DASAR NEGERI O03 BANGKINANG KOTA
}

\author{
Yenni Fitra Surya \\ Universitas Pahlawan Tuanku Tambusai, Jl. Tuanku Tambusai No 23 Bangkinang \\ Yenni.fitra13@gmail.com
}

\begin{abstract}
Abstrack
Penelitian ini dilatarbelakangi oleh rendahnya hasil belajar Matematika diperoleh siswa kelas V secara klasikal masih berada di bawah ketuntasan yang ditetapkan yaitu $85 \%$. Berdasarkan observasi awal yang dilakukan di Sekolah Dasar Negeri 003 Bangkinang dijumpai gejala-gejala seperti: 1) Hasil tes pada siswa kelas V Sekolah Dasar Negeri 003 Bangkinang diperoleh fakta tentang hasil belajar Matematika dari 33 siswa ternyata yang mencapai KKM yang ditetapkan sekolah yaitu 70 sebanyak 13 orang siswa (39.39\%) dan yang tidak mencapai KKM sebanyak 20 siswa $(59,4 \%)$ dengan nilai rata-rata 67,5. 2) Siswa cenderung bosan dalam mengikuti pelajaran Matematika, 3) Kurangnya keingintahuan siswa terhadap pelajaran yang disampaikan oleh guru di kelas, dan 4) Selama ini guru cenderung menjelaskan materi, memberikan contoh soal dan memberi latihan dengan cara yang monoton. Penelitian ini bertujuan untuk mengetahui peningkatan hasil belajar Matematika pada materi pecahan siswa kelas V Sekolah Dasar Negeri 003 Bangkinang melalui penerapan model pembelajaran kooperatif tipe Team Games Tournament (TGT).

Penelitian ini merupakan penelitian tindakan kelas.penelitian tindakan kelas merupakan suatu pencermatan terhadap kegiatan belajar berupa sebuah tindakan yang sengaja dimunculkan dan terjadi dalam sebuah kelas secara bersama. Tindakan tersebut diberikan oleh guru atau dengan arahan dari guru yang dilakukan oleh siswa.Penelian ini telah dilaksanakan di kelas V Sekolah Dasar Negeri 003.

Berdasarkan hasil penelitian, maka dapat diketahui bahwa Ketuntasan belajar siswa meningkat pada siklus I dari 33 orang siswa, yang mencapai ketuntasan berjumlah 20 orang siswa $(60.6 \%)$ dan siswa yang tidak tuntas 13 orang $(39.4 \%)$. Sedangkan pada siklus II siswa yang dikatakan tuntas 29 orang $(87.9 \%)$ dan siswa yang tidak tuntas 4 orang $(12.1 \%)$. Sedangkan nilai rata-rata peningkatan hasil belajar siswa dari data awal ke siklus I sebesar 5.5 dan dari siklus I ke siklus II juga mengalami peningkatan sebesar 10,30.
\end{abstract}

Keywords: Learning Outcomes, RME Approach, Fractions

\begin{abstract}
Abstrak
This research is motivated by the low of learning result of Mathematics obtained by class V students classically still under the determined mastery that is $85 \%$. Based on preliminary observations conducted at State Elementary School 003 Bangkinang encountered symptoms such as: 1) The test results on the students of grade V of State Elementary School 003 Bangkinang obtained facts about the mathematics learning outcomes of 33 students turned out to reach KKM established by the school that is 70 as many as 13 students $(39.39 \%)$ and those who did not reach the KKM were 20 students (59.4\%) with an average score of 67.5. 2) Students tend to be bored in following Mathematics lessons, 3) Lack of students' curiosity about the lessons conveyed by teachers in the classroom, and 4) During this time teachers tend to explain the material, give examples of problems and give practice in a monotonous way. This study aims to determine the improvement of mathematics learning outcomes in the fractional material of grade V students of State Elementary School 003 Bangkinang through the implementation of cooperative learning model of Team Games Tournament (TGT) type. This study is a classroom action research. Classroom action research is a reflection of learning activities in the form of an act that deliberately appears and occurs in a class together. The action is given by the teacher or by the direction of the teacher conducted by the student. This purchase has been conducted in the V of the State Elementary School V 003.
\end{abstract}


Based on the result of the research, it can be seen that the students' learning mastery improved on the first cycle of 33 students, which reached the completeness of 20 students $(60.6 \%)$ and the unfinished student 13 people (39.4\%). While on the second cycle of students who said 29 thorough people $(87.9 \%)$ and students who are not complete 4 people $(12.1 \%)$. While the average value of student learning outcomes from the initial data to the first cycle of 5.5 and from cycle I to cycle II also increased by 10.30 .

\section{Kata Kunci: Hasil Belajar, Pendekatan RME, Pecahan}

Banyak orang yang memandang Matematika sebagai bidang studi yang paling sulit.Meskipun demikian, semua orang harus mempelajarinya karena merupakan sarana untuk memecahkan masalah kehidupan sehari-hari.Seperti halnya bahasa, membaca, dan menulis.Kesulitan Matematika harus diatasi sedini mungkin. Kalau tidak, siswa akan menghadapi banyak masalah karena hampir semua bidang studi memerlukan Matematika yang sesuai (misal:fisika). Matematika merupakan ilmu yang abstrak dan deduktif.Anak disekolah (terutama SD) masih berfikir secara konkret dan induktif.Siswa dapat memahami konsep-konsep Matematika dengan baik jika pengajaran mulai dari yang konkret ke abstrak. Seperti apa yang diharapkan dalam tujuan pembelajaran Matematika pada kurikulum 2006.

Matematika merupakan ilmu yang universal yang mendasari pengembangan tekhnologi modern, mempunyai peran penting dalam berbagai disiplin dan memajukan daya pikir manusia.Perkembangan pesat di bidang tekhnologi informasi dan komunikasi ini dilandasi oleh perkembangan matematika di bidang teori bilangan, aljabar, analisis teori peluang dan matematika diskrit. Untuk menguasai dan mencipta teknologi di masa depan diperlukan penguasaan matematika yang kuat sejak dini

Keberhasilan siswa dalam penguasaan materi mata pelajaran Matematika dapat dilihat dari hasil belajar Matematika. Siswa dikatakan berhasil jika hasil belajar Matematikanya mencapai Kriteria Ketuntasan Minimum (KKM) mata pelajaran Matematika yang telah ditetapkan oleh setiap sekolah. Sebaliknya jika siswa tersebut mendapat nilai dibawah nilai standar ketuntasan yang telah ditetapkan, maka siswa tersebut belum dapat dikatakan berhasil dalam belajar Matematika

Mengingat pentingnya pembelajaran Matematika maka diharapkan siswa dapat menguasai Matematika dengan baik terutama untuk setiap kompetensi dasar yang telah ditetapkan dalam kurikulum pendidikan Matematika. Keberhasilan siswa dalam belajar Matematika akan memberikan perubahan pada cara berpikir dan perubahan pada tingkah laku siswa. Keberhasilan belajar Matematika tidak terlepas dari kualitas pengajar yang dilakukan.Kualitas pengajaran mempunyai hubungan berbanding lurus dengan hasil belajar.Artinya semakin tinggi kualitas pengajaran semakin tinggi pula hasil belajar yang diperoleh. Kualitas pengajaran yang dimaksud adalah tinggi rendahnya atau efektif tidaknya proses pembelajaran. Proses pembelajaran dikatakan efektif bila siswa secara aktif dilibatkan dalam menemukan sendiri hubungan informasi yang diperoleh.

Berdasarkan observasi awal yang dilakukan di Sekolah Dasar Negeri 003 Bangkinang Kota dijumpai gejala-gejala sebagai berikut : 
1. Hasil tes pada siswa kelas V Sekolah Dasar Negeri 003 Bangkinang Kota diperoleh fakta tentang hasil belajar Matematika dari 33 siswa ternyata yang mencapai KKM yang ditetapkan sekolah yaitu 70 sebanyak 13 orang siswa (39.39\%) dan yang tidak mencapai KKM sebanyak 20 siswa $(59,4 \%)$ dengan nilai rata-rata 67,5 .

2. Siswa cenderung bosan dalam mengikuti pelajaran Matematika

3. Kurangnya keingintahuan siswa terhadap pelajaran yang disampaikan oleh guru di kelas.

4. Selama ini guru cenderung menjelaskan materi, memberikan contoh soal dan memberi latihan dengan cara yang monoton. Disini guru hanya berfungsi sebagai pemberi pengetahuan dan siswa penerima pengetahuan sehingga siswa bersikap pasif dalam proses pembelajaran. Hal ini terlihat dari kegiatan siswa yang cenderung lebih banyak diam, mendengarkan tanpa ada memberikan pertanyaaan atau tanggapan

Berdasarkan gejala-gejala tersebut, maka perlu dilakukan perbaikan dan pembaharuan dalam kegiatan belajar. Perlu diterapkan suatu model pembelajaran yang dapat mengaktifkan siswa secara keseluruhan, memberi kesempatan kepada siswa untuk mengembangkan potensinya secara maksimal sekaligus mengembangkan aspek kepribadian seperti kerja sama, bertanggung jawab dan disiplin. Salah satu model yang dapatmeningkatkan hasil belajar siswa sehingga memunculkan suasana yang mendukung dalam belajar adalah dengan menggunakan model pembelajaran Kooperatif tipe Team Games Tournament (TGT) atau dapat juga diartikan sebagai turnamen antar tim atau pertandingan antar tim, karena di dalamnya terdapat unsur permainan, pemahaman karakter, situasi, partisipasi dan aktualisasi diri dalam menggali bakat dan potensi diri siswa, serta kerja sama dan rasa tepa selira antar anggota kelompok belajar juga persaingan yang sehat.

Berdasarkan uraian yang telah dikemukakan di atas, maka peneliti berkeinginan untuk mengadakan suatu penelitian dengan judul "Penerapan Model Pembelajaran Kooperatif Tipe Team Games Tournament (TGT) Untuk Meningkatkan Hasil Belajar Matematika Siswa Kelas V Sekolah Dasar Negeri 003 Bangkinang Kota”.

Menurut Kunandar (2010:359) menyatakan bahwa pembelajaran kooperatif adalah pembelajaran yang secara sadar dan sengaja mengembangkan interaksi yang saling asuh antar siswa untuk menghindari ketersinggungan dan kesalahpahaman yang dapat menimbulkan permusuhan. Wena (2011:189), menambahkan melalui pembelajaran kooperatif akan memberi kesempatan pada siswa untuk bekerja sama denga sesama siswa dalam tugas-tugas yang terstruktur. Melalui pembelajaran kooperatif pula, seorang siswa akan menjadi sumber belajar bagi temannya.

Sedangkan menurut Majid (2013:174), menyatakan bahwa pembelajaran kooperatif adalah model pembelajaran yang mengutamakan kerja sama untuk mencapai tujuan pembelajaran. Pembelajaran kooperatif merupakan bentuk pembelajaran dengan cara siswa belajar aktif dan bekerja sama dalam kelompok-kelompok kecil secara kolaboratif yang anggotanya terdiri dari 4 sampai 6 orang orang dengan struktur kelompok yang bersifat berbeda (heterogen). 
Isjoni (2011:83-84), Team Game Tournament adalah salah satu tipe pembelajaran kooperatif yang menempatkan siswa dalam kelompok-kelompok belajar yang beranggotakan $5-6$ orang siswa yang memiliki kemampuan, jenis kelamin, dan suku kata atau ruas yang berbeda. Guru menyajikan materi, siswa bekerja dalam kelompok mereka masing-masing. Dalam kerja kelompok guru memberikan LKS kepada setiap kelompok.Tugas yang diberikan dikerjakan bersama-sama dengan anggota kelompoknya. Apabila ada dari anggota kelompok yang tidak mengerti dengan tugas yang diberikan, maka anggota kelompok yang lain bertanggung jawab untuk memberikan jawaban atau memjelaskannya, sebelum mengajukan pertanyaan tersebut kepada guru.

Slavin (2008:167) menyatakan bahwa pembelajaran kooperatif model Team Game Tournament(TGT) adalah salah satu tipe atau model pembelajaran kooperatif yang mudah diterapkan, melibatkan aktivitas seluruh siswa tanpa harus ada perbedaan status, melibatkan peran siswa sebagai tutor sebaya dan mengandung unsur permainan dan reinforcement. Para siswa mengerjakan lembaran kegiatan dalam tim mereka untuk menguasai materi. Para siswa memainkan game akademik dalam kemampuan yang homogen dengan meja turnamen tiga peserta. Skor tim dihitung berdasarkan skor turnamen anggota tim, dan tim tersebut akan direkognisi apabila mereka berhasil melampaui kriteria yang telah ditetapkan sebelumnya.

\section{METODE PENELITIAN}

Dalam penelitian ini, metode yang digunakan adalah metode penelitian tindakan kelas (PTK).Berikut ini adalah berbagai pengertian PTK (penelitian tindakan kelas) menurut para ahli dalam Kunandar (2011: 43):

1. Menurut Kemmis dan Taggart: Penelitian tindakan adalah suatu bentuk self-inquiry kolektif yang dilakukan oleh para partisipan didalam situasi sosial untuk meningkatkan rasionalitas dan keadilan dari praktik pendidikan dan praktik sosial mereka, serta mempertinggi pemahaman mereka terhadap praktik dan situasi dimana praktik itu dilaksanakan.

2. Kurt Lewin: penelitian tindakan adalah suatu rangkaian langkah yang terdiri atas empat tahap, yakni perencanaan, tindakan, pengamatan, dan refleksi.

3. Ebbut: penelitian tindakan adalah kajian sistematik dari upaya perbaikan pelaksanaan praktik pendidikan oleh sekelompok guru dengan melakukan tindakan-tindakan dalam pembelajaran, berdasarkan refleksi mereka mengenai hasil dari tindakan tersebut.

4. David Hopkins: PTK adalah sebuah bentuk kegiatan refleksi dari yang dilakukan oleh para pelaku pendidikan dalam suatu situasi kependidikan untuk memperbaiki rasionalitas dan keadilan tentang: (a) praktik-praktik kependidikan mereka, (b) pemahaman mereka tentang praktik-praktik tersebut, (c) situasi dimana praktik-praktik tersebut dilaksanakan.

Berdasarkan pengertian di atas penelitian tindakan kelas dapat didefinisikan sebagai suatu penelitian tindakan (action research) yang dilakukan oleh guru yang sekaligus sebagai peneliti di kelasnya atau bersama-sama dengan orang lain (kolaborasi) dengan jalan merancang, melaksanakan, 
dan merefleksikan tindakan secara kolaboratif dan partisipatif yang bertujuan untuk memperbaiki atau meningkatkan mutu proses pembelajaran di kelasnya melalui suatu tindakan tertentu dalam suatu siklus.

Mengingat dalam suatu penelitian tindakan kelas peneliti perlu dibantu oleh pendamping sebagai rekan diskusi bagi peneliti, maka dalam hal ini peneliti meminta bantuan guru kelas sebagai pengamat dalam penelitian, mulai dari perencanaan tindakan, pelaksanaan tindakan, observasi, refleksi, dan revisi selama peneliti melakukan penelitian di SDN 003 Bangkinang Kota. Penelitian tindakan kelas ini dilaksanakan melalui tahap-tahap yang umumnya dilaksanakan dalam suatu penelitian tindakan kelas.Tahap-tahap tersebut biasa disebut dengan siklus, dimana setiap siklusnya meliputi perencanaan, pelaksanaan tindakan, observasi, evaluasi, dan refleksi.

Kegiatan penelitian dilaksanakan berdasarkan perencanaan tindakan yang telah ditetapkan, yaitu melaksanakan pembelajaran sesuai rencana pembelajaran yang telah dibuat.Fokus tindakan adalah penggunaan model pembelajaran kooperatif tipe TGT yang dioptimalkan untuk meningkatkan hasil belajar siswa.Pada tahap pelaksanaan tindakan ini, proses pembelajaran dilaksanakan dengan menjalankan skenario pembelajaran yang telah dirancang dan terdapat dalam RPP.

Disaat tahapan pelaksanaan tindakan sedang berlangsung, pada waktu yang sama peneliti juga melaksanakan tahapan observasi. Pada tahap observasi ini, peneliti dibantu oleh pengamat penelitian (observer) mengumpulkan data untuk mendapatkan informasi terkait dengan proses pembelajaran. Hal ini dimaksudkan agar informasi yang ditemukan dapat lebih diorganisir pada lembar observasi untuk memperoleh kesimpulan dari proses pembelajaran. Hasil observasi proses pembelajaran inilah yang akan digunakan untuk analisis dan refleksi untuk menentukan langkah yang selanjutnya dalam penelitian tindakan kelas ini. Pada tahap pelaksanaan tindakan, peneliti juga memberikan tes ketercapaian indikator kepada siswa, tes ini untuk mengetahui peningkatan pemahaman materi siswa berdasarkan aspek kognitif.

\section{HASIL DAN PEMBAHASAN}

Berdasarkan analisis hasil tindakan yang telah dikemukakan di atas, dapat disimpulkan bahwa ketercapaian tentang aktivitas guru, aktivitas siswa dan ketercapaian hasil belajar Matematika baik secara individu maupun klasikal telah sesuai dengan perencanaan. Belajar yang menyerupai permainan akan menciptakan pembelajaran menjadi lebih menyenangkan dan tidak membosankan dibandingkan dengan mengerjakan informasi sulit dengan cara biasa, sehingga tujuan yang diinginkan dapat tercapai. Rata-rata nilai siswa sebelum tindakan memperoleh 62.4 meningkat pada siklus I meningkat menjadi 67,9. Setelah melakasanakna tindakan pada siklus II, hasil belajar pada ulangan harian II, nilai rata-rata siswa meningkat menjadi 78.2.Untuk melihat ketuntasan belajar pada siklus I dan siklus II di kelas V SD Negeri 003 Bangkinang dapat dilihat pada grafik di bawah ini. 


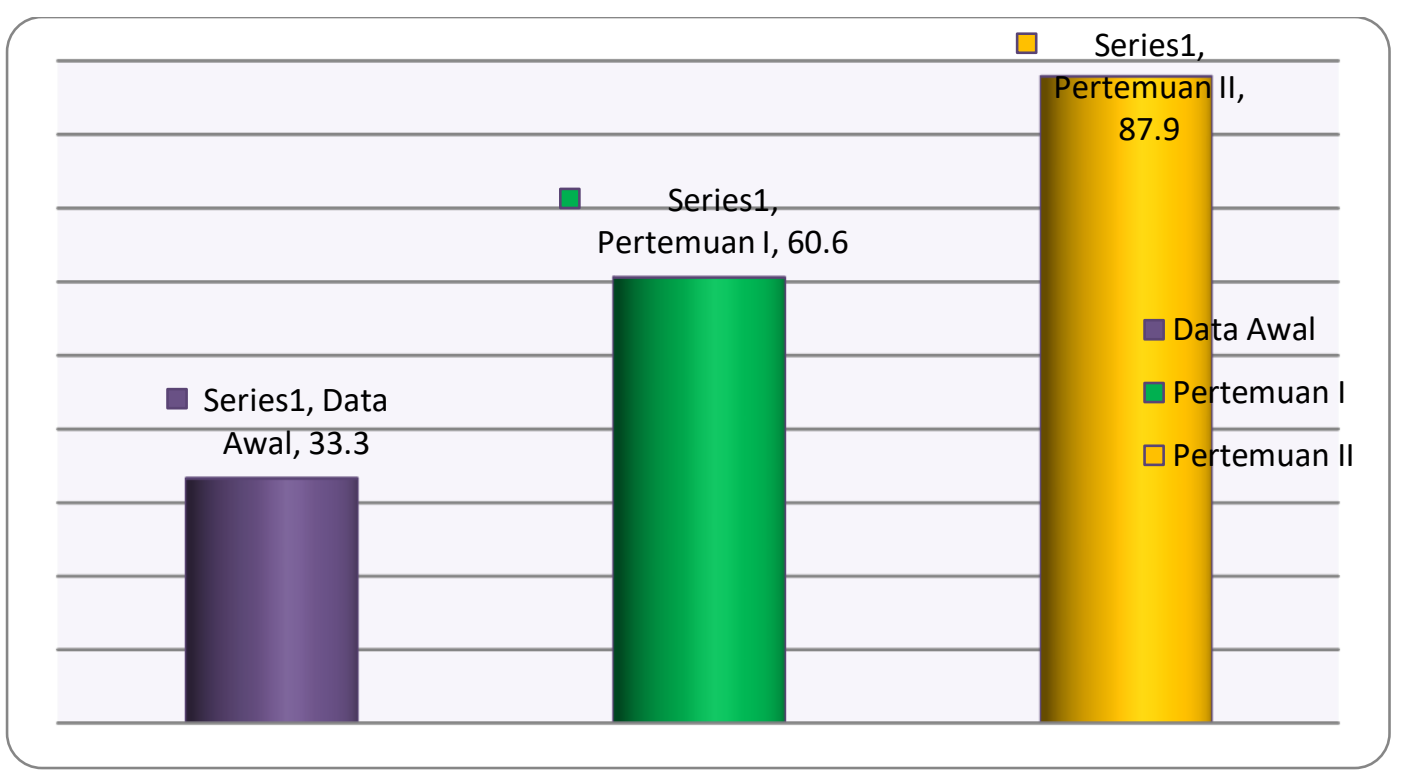

Grafik 4.1

HASIL BELAJAR SISWA

Berdasarkan grafik diatas, dapat disimpulkan bahwa nilai ketuntasan siswa sebelum melaksanakan model pembelajaran kooperatif tipe TGT diperoleh 33.3\%, artinya nilai ketuntasan klasikal belum mencapai nilai ketuntasan yang diharapkan yaitu 85\% (Wardani, 2004:4.12). Setelah dilaksanakan ulangan harian siklus I, nilai ketuntasan siswa meningkat mencapai 60.6\%.siswa yang tuntas pada siklus I yaitu 20 dari 33 orang siswa. Nilai ketuntasan pada siklus I belum mencapai nilai ketuntasan yang ditetapkan artinya penelitian dengan penerapan model pembelajaran kooperatif tipe TGT dilanjutkan pada siklus berikutnya.Pada siklus II, nilai ketuntasan klasikal siswa mencapai nilai ketuntasan yang diharapkan mencapai 87.9\%.Siswa yang tuntas pada siklus II ini sebanyak 29 dari 33 siswa. Artinya, dengan penerapan model pembelajaran kooperatif tipe TGT dapat meningkatkan hasil belajar siswa.

Pandangan guru terhadap aktivitas siswa selama melaksanakan proses pembelajaran di kelas V SD Negeri 003 Bangkinang, terlihat siswa sangat bersemangat dalam mengikuti proses pembelajaran. Hal ini dikarenakan, siswa dalam proses pembelajaran dilatih untuk bekerjasama dalam mengerjakan tugas yang diberikan guru dalam kelompok belajar, menyajikan hasil diskusi di depan kelas, aktif bertanya dan memberikan tanggapan saat penyajian diskusi, aktif dalam turnamen dan bersaing secara sehat dalam melaksanakan turnamen. Dalam hal ini sebaiknya guru harus bisa mengkoordinir jalannya interaksi belajar supaya proses pembelajaran berjalan sesuai dengan yang direncanakan. Hal ini sesuai dengan Waini Rasyidin dalam Slameto (2003:24) mengatakan bahwa guru merupakan koordinator yang melakukan aktivitas dalam interaksi sedemikian rupa sehingga siswa belajar seperti yang diinginkan.

Untuk melihat peningkatan aktivitas siswa dalam belajar pada siklus I dan siklus II di kelas V SD Negeri 003 Bangkinangdapat dilihat dengan jelas pada grafik dibawah ini. 


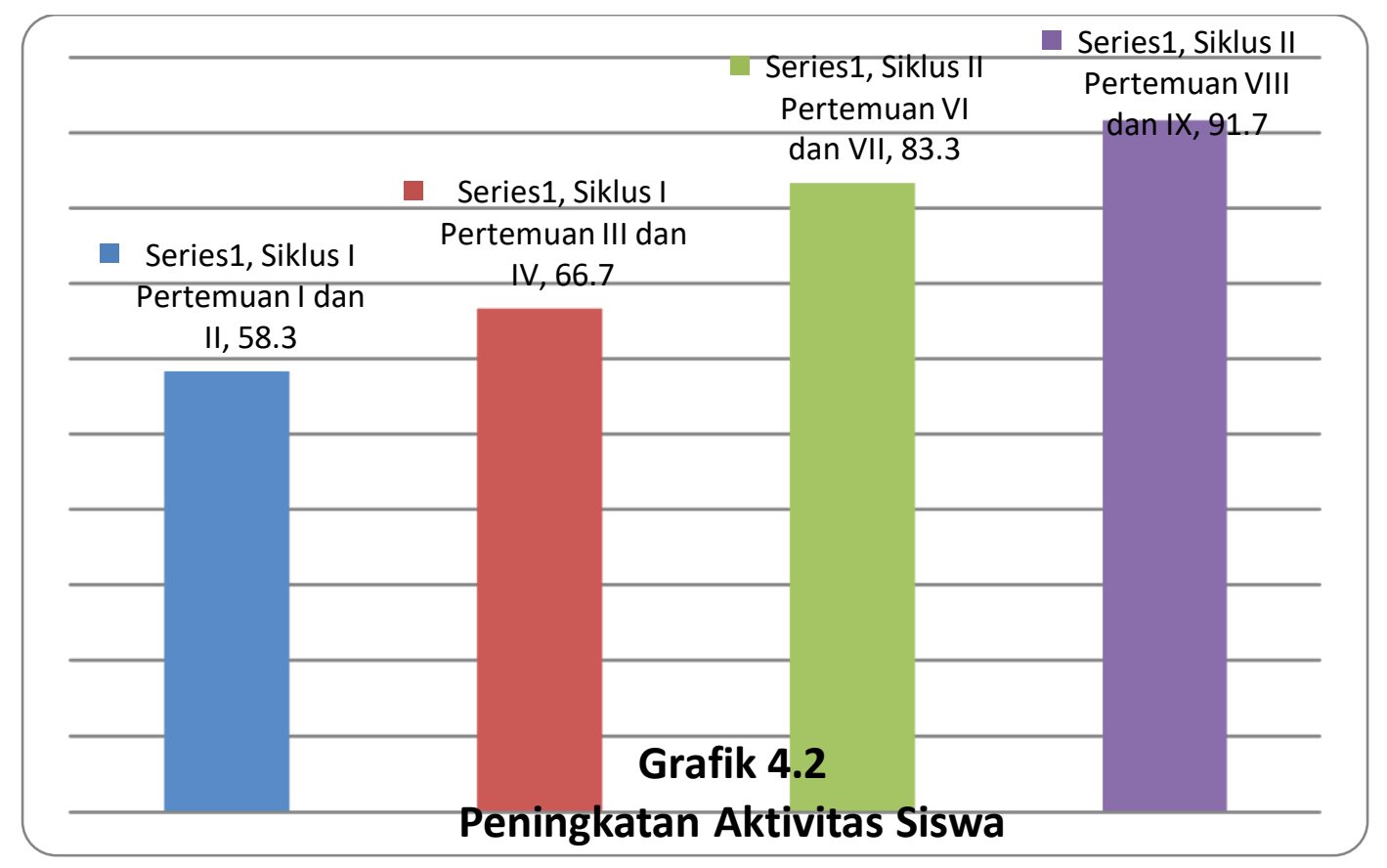

Berdasarkan grafik di atas, aktivitas siswa meningkat pada setiap pertemuannya. Pada pertemuan pertama dan kedua dalam melaksanakan model pembelajaran kooperatif tipe TGT aktivitas siswa memperoleh persentasi sebesar $58.3 \%$, selanjutnya pada pertemuan ketiga dan keempat meningkat menjadi 66.7\%. Peningkatan ini terjadi karena adanya interaksi antara guru dengan siswa dan siswa dengan siswa.Selanjutnya pada siklus II pertemuan keenam dan ketujuh diperoleh persentasi aktivitas siswa sebesar $83.3 \%$ dan pertemuan kedelapan dan kesembilan meningkat menjadi $91.7 \%$.

Aktivitas guru dalam penelitian ini meningkat disebabkan karena guru semakin mengerti dalam menerapkan pembelajaran sehingga siswa termotivasi dan berdampak pada kenaikan persentase aktivitas siswa. Peran dan fungsi guru sangat menentukan serta mempunyai pengaruh yang sangat besar terhadap peningkatan hasil belajar (Slameto,2003:25). Untuk melihat peningkatan aktivitas guru pada siklus I dan siklus II di kelas V SD Negeri 003 Bangkinang dapat dilihat dengan jelas pada grafik dibawah ini. 


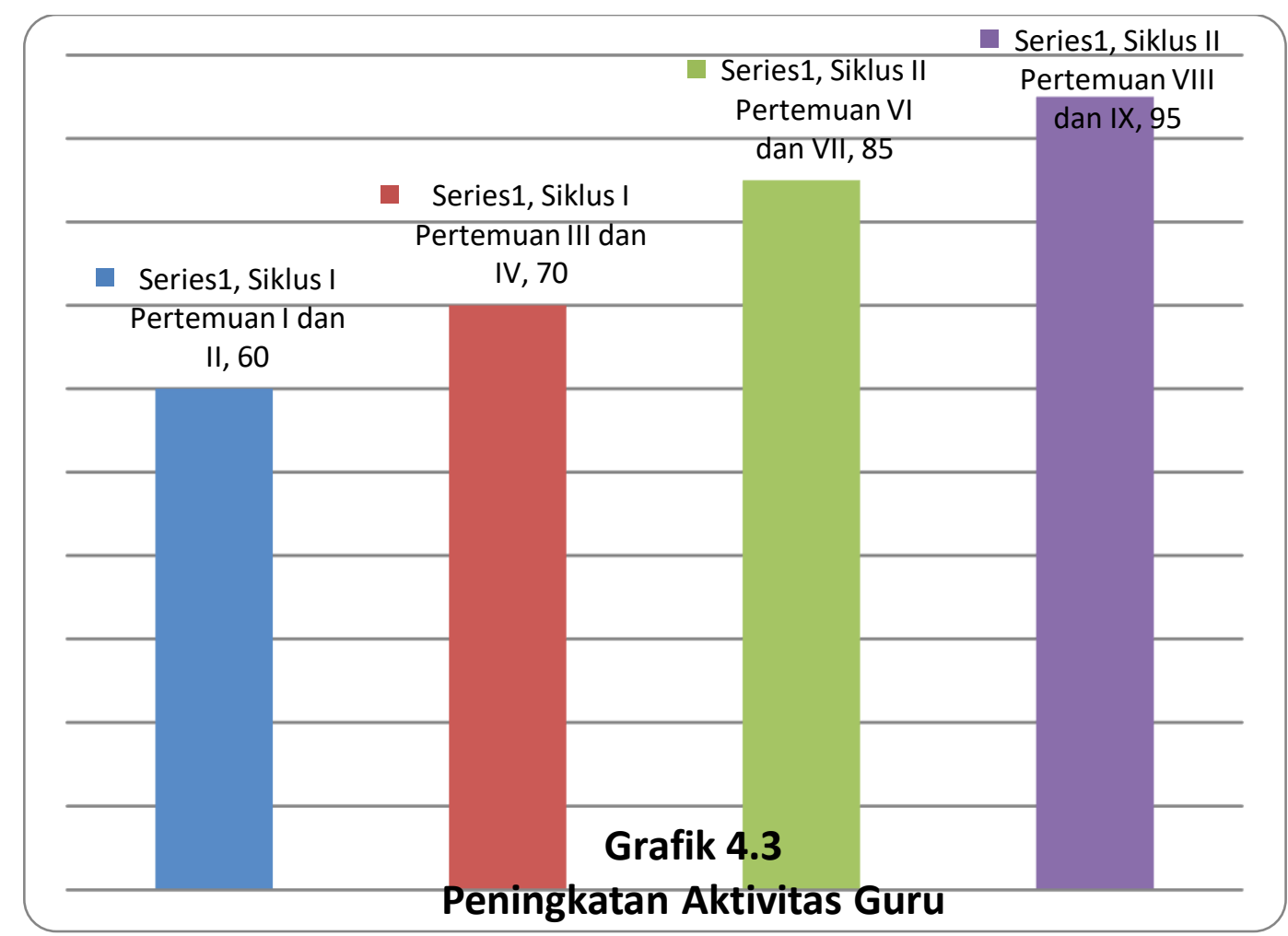

Berdasarkan grafik di atas, dapat dilihat pada pertemuan pertama dan kedua dalam melaksanakan model pembelajaran kooperatif tipe TGT aktivitas guru memperoleh persentasi yaitu $60 \%$, selanjutnya pada pertemuan ketiga dan keempat meningkat menjadi 70\%. Aktivitas guru pada siklus I masih rendah, selanjutnya pada siklus II pertemuan keenam dan ketujuh diperoleh persentasi aktivitas guru sebesar 85\% dan pertemuan kedelapan dan kesembilan meningkat menjadi $95 \%$.

Berdasarkan hasil penelitian di atas, dapat disimpulkan bahwa penerapan pembelajaran kooperatif tipe TGT dapat memperbaiki proses pembelajaran dan meningkatkan hasil belajar Matematika siswa. Hal ini terbukti karena pada pembelajaran kooperatif tipe TGT, siswa melaksanakan permainan dalam bentuk turnamen. Permainan dalam bentuk turnamen ini terbukti sangat dikuasai oleh siswa dan selalu ditunggu oleh siswa pada setiap pertemuan. Siswa juga diajarkan untuk bersaing secara sehat dalam kelas tersebut untuk menjadikan kelompok belajar mereka sebagai kelompok super.

Permainan dalam bentuk turnamen tersebut dapat mengaktifkan siswa dalam proses pembelajaran. Selain itu, diskusi dalam kelompok untuk mengerjakan LKS dan menyajikan hasil diskusi juga dapat membuat siswa terlibat secara aktif dalam proses pembelajaran. Sehingga dengan terlibat aktifnya siswa dalam proses pembelajaran dan didukung oleh semangat belajar siswa yang tinggi, dapat meningkatkan hasil belajar Matematika siswa kelas V SD Negeri 003 Bangkinang.

Pembelajaran dengan model pembelajaran kooperatif tipe TGT (Team Game Tournament) ini dinilai berhasil karena bukan aktivitas guru saja yang meningkat melainkan hasil belajar siswa juga meningkat dan siswa sudah bisa lebih aktif menyampaikan pendapatnya dalam kelompok, saling kerjasama, bertanggung jawab dan berani bertanya kepada guru dan teman-teman 
kelompoknya.Melalui model pembelajaran kooperatif tipe TGT (Team Game Tournament) dapat membantu siswa dalam meningkatkan pengetahuan yang dimilikinya.

Namun demikian secara umum dari analisis tindakan terdapat peningkatan skor (nilai) hasil belajar setelah diadakannya tindakan.Sehingga dapat disimpulkan bahwa pembelajaran model pembelajaran kooperatif tipe TGT (Team Game Tournament) dapat meningkatkan hasil belajar Matematika siswa kelas V SD Negeri 003 Bangkinang.

Sesuai dengan pendapat Mulyasa (2009:11) tentang penelitian tindakan kelas, dan memperhatikan pembelajaran di atas dapat disimpulkan bahwa hipotesis tindakan dapat diterima kebenarannya. Dengan kata lain bahwapenerapan model pembelajaran kooperatif tipe TGT(Team Game Tournament) dalam pembelajaran di kelas V SD Negeri 003 Bangkinang dapat meningkatkan hasil belajar Matematika siswa.

\section{KESIMPULAN}

Dari hasil penelitian yang telah dilakukan dapat disimpulkan bahwa penerapanpembelajaran model pembelajaran kooperatif tipe Team Game Tournament (TGT) dapat meningkatkan hasil belajar Matematika siswa kelas V SD Negeri 25 Pekanbaru. Hal ini ditunjukkan pada rata-rata persentase tiap parameter sebagai berikut :

1. Rata-rata peningkatan hasil belajar siswa dari data awal ke siklus I sebesar 5.5 dan dari siklus I ke siklus II juga mengalami peningkatan sebesar 10,30.

2. Ketuntasan belajar siswa meningkat pada siklus I dari 33 orang siswa, yang mencapai ketuntasan berjumlah 20 orang siswa (60.6\%) dan siswa yang tidak tuntas 13 orang (39.4\%). Sedangkan pada siklus II siswa yang dikatakan tuntas 29 orang (87.9\%) dan siswa yang tidak tuntas 4 orang (12.1\%).

3. Aktivitas guru dalam melaksanakan pembelajaran meningkat dari $65 \%$ dengan kategori sedang pada siklus I menjadi 90\% dengan kategori sangat baik pada siklus II.

4. Aktivitas belajar siswa dalam pembelajaran mengalami peningkatan dari $62,5 \%$ dengan kategori sedang pada siklus I menjadi 87,5\% dengan kategori baik pada siklus II.

\section{DAFTAR PUSTAKA}

Astuti, A. (2016). Penerapan Metode Penemuan Terbimbing Untuk Meningkatkan Aktivitas Dan Hasil Belajar Matematikasiswa Kelas Xii Ips Sma Negeri 1 Salo. Jurnal Cendekia : Jurnal Pendidikan Matematika, (1), 1-14. Retrieved From Http://Journal.Stkiptam.Ac.Id/Index.Php/Cendekia/Article/View/646

Arikunto, Suharsimi, Dkk. 2006.Penelitian Tindakan Kelas.Jakarta: Bumi Aksara.

Depdiknas. 2006.Kurikulum Tingkat Satuan Pendidikan.Jakarta: Pusat Kurikulum, Balitbang Depdiknas.

Dimyati dan Mudjiono. 2006. Belajar dan Pembelajaran. Jakarta: Rineka Cipta 
Djamarah,S. Bahri. 2006. Strategi Belajar Mengajar. Jakarta: Rineka Cipta.

Ibrahim, 2000.Pembelajaran Kooperatif. Jakarta; Rajawali Press

Kunandar.2010. Guru Profesional Implementasi Kurikulum Tingkat Satuan Pendidikan (KTSP) Dan Persiapan Menghadapi Sertifikasi Guru. Jakarta: PT. Raja Grafindo Persada

Mulyasa.2009. Manajemen Berbasis Sekolah Bandung. PT. Remaja Rosdakarya

Sanjaya. 2010. Strategi Pembelajaran Berorientasi Standar Proses Pendidikan. Jakarta: Kencana

Slavin, Robert E. 2010.Cooperative learning Teori, Riset dan Praktis. Bandung: Nusa Media

Soedjadi, R. 2000. Kiat Pendidikan Matematika di Indonesia. Jakarta: Depdiknas

Sudjana, N. 2008.Proses Belajar Mengajar.Bandung: Pustaka Pelajar

Wena, M. 2011. Strategi Pembelajaran Inovatif Kontemporer, Jakarta, PT. Bumi Aksara

Zulfah, Z. (2018). Pengaruh Penerapan Model Pembelajaran Kooperatif Tipe Think Pair Share Dengan Pendekatan Heuristik Terhadap Kemampuan Pemecahan Masalah Matematis Siswa Mts Negeri Naumbai Kecamatan Kampar.Jurnal Cendekia : Jurnal Pendidikan Matematika, (2), 65-76. Retrieved From Http://Journal.Stkiptam.Ac.Id/Index.Php/Cendekia/Article/View/634 